\title{
A hepatitis C-vírus-fertőzés és hepatocarcinogenesis
}

\author{
SZALAY FERENC DR. \\ Semmelweis Egyetem, Általános Orvostudományi Kar, I. Belgyógyászati Klinika, Budapest
}

\begin{abstract}
Ma már bizonyított, hogy nemcsak a HBV-, hanem a HCV-infekció is krónikus hepatitist, májcirrhosist és hepatocellularis májrákot (HCC) okozhat. A hepatitis C-vírus is onkogén vírusnak minősül. A két különböző vírus által indukált májrák kialakulásának mechanizmusa több közös és számos eltérő sajátságot mutat. Mindkét esetben többnyire hosszú évekig, akár évtizedekig tartó krónikus gyulladás által okozott májcirrhosis talaján alakul ki a májrák. A HCV mint RNS-vírus nem épül be a májsejt genomjába, hanem különböző utakon indukálja a ráksejtek kialakulását, amelyek azután kontroll nélkül proliferálnak. Már a HCV felfedezése előtt felfigyeltek az akkor még non-A-non-B-nek (NANB) nevezett hepatitis és a májrák közötti kapcsolatra. A későbbi epidemiológiai jellegủ tanulmányok ezt megerősítették. Számos közlés van azonban arról, hogy a HCC cirrhosis nélkül is kialakulhat HCVfertőzött egyénekben. A pontos mechanizmus nem ismert, de több adat utal arra, hogy a vírus bizonyos proteinjei képesek onkogén folyamatot indukálni. A HCV-core gén több pontján találtak különbséget a cirrhosis nélküli és a cirrhosis talaján kialakult HCCben. Feltételezhetó, hogy a vírus az endoplazmás reticulumstressz és az oxidatív stressz következményeként különböző jelátviteli utak és az onkogén útvonalak direkt aktiválása révén fejti ki karcinogén hatását. Újabb adatok szerint a HCV inzulinrezisztenciát okozó hatásának is szerepe lehet az onkogenezisben. A vírus által determinált faktorok mellett a gazdaszervezet reakciójának, a tumor elleni védekezóképesség csökkenésének is szerepe van a májrák kialakulásában. Klinikai szempontból fontos a HCVinfekcióban szenvedő betegek rendszeres ellenőrzése tumorkialakulás szempontjából. A monitorozás fő eszköze az ultrahangvizsgálat. Az AFP csak az esetek egy részében pozitív. A már kialakult és diagnosztizált májrák kezelési stratégiája nem tér el a többi májbetegségben kialakult májrákétól. Orv. Hetil., 2010, 38, 1524-1529.
\end{abstract}

Kulcsszavak: hepatitis C-virus, hepatocellularis carcinoma, hepatocarcinogenesis

\section{Hepatitis $\mathrm{C}$ virus infection and hepatocarcinogenesis}

It is evidenced that both HBV and HCV infections may cause chronic hepatitis, liver cirrhosis and hepatocellular carcinoma (HCC). $\mathrm{HCV}$ is considered as an oncogen virus. The mechanism of carcinogenesis in case of the two distinct viruses shows a number of common and different features. HCC usually develops in stage of liver cirrhosis caused by chronic inflammation of many years or decades. In contrast to HBC, HCV will not be incorporated into the genom of hepatocytes. It induces throughout different mechanisms the development of cancer cells, which will proliferate out of control. Before the discovery of HCV, the connection of non-A non-B (NANB) hepatitis and liver cancer has yet been observed. The subsequent epidemiological studies confirmed this association. A number of publications prove that HCC may develop without cirrhosis in HCV infected patients. The exact mechanism is not known, but data indicate that some proteins of the virus may induce oncogenic process. Differences were found in HCV core gene between HCC patients with and without cirrhosis. It is postulated that the virus evolves its oncogenic effect via endoplasmic and oxidative stress, further on by activation of different oncogenic signal pathways. Recent publications indicate the role of virus induced insulin resistance. Besides the virus determined factors, the host reaction, the deficient tumor cell eliminating capacity may also have a role in the development of liver carcinoma. Monitoring of HCV infected patients for HCC is an important clinical issue. Most relevant is the regular ultrasound cheek up. Serum alpha fetoprotein level is elevated only in a smaller proportion of the patients. The treatment protocol of HCV induced HCC does not differ from the others developed in non-HCV liver diseases. Orv. Hetil., 2010, 38, 1524-1529.

Keywords: hepatitis C virus, hepatocellular carcinoma, hepatocarcinogenesis

(Beérkezett: 2010. június 16.; elfogadva: 2010. augusztus 3.)

A hepatocellularis carcinoma (HCC) az egyik leggyakoribb rosszindulatú daganat. Ma már bizonyított, hogy a primer májrák keletkezésében számos tényező mellett a hepatitis $\mathrm{C}(\mathrm{HCV})$-infekciónak is jelentös szerepe van. A HCV onkogén vírusnak minősül [1]. A HCC előfordulásában és a kiváltó okok arányában jelentős földrajzi különbségek vannak. Ázsiában a HBV, Észak-Amerikában, Japánban és Európában, így hazánkban is, a HCV a leggyakoribb kockázati tényező. A nyugati országokban a HCC incidenciája növekvóben van [2]. Bár a betegség előfordulása az életkor előrehaladtával gyakoribb, a prevalencia 65 éves kor felett a legnagyobb; az 
utóbbi időben eltolódás figyelhető meg a fiatalabb életkor felé [3].

A két különböző vírus által indukált májrák kialakulásának mechanizmusa több közös, és számos eltérő sajátságot mutat. Mindkét esetben közös, hogy többnyire hosszú évekig, akár évtizedekig tartó krónikus gyulladás által okozott májcirrhosis talaján alakul ki a májrák. Számos közlés van azonban arról, hogy a HCC cirrhosis nélkül is kialakulhat HCV-fertőzött egyénekben $[4,5]$.

A HCV által indukált májrák kialakulásáról egyre több adatot ismerünk, egyre több tényező szerepére derült fény, de a pontos mechanizmus még nem ismert. A HCV onkogenitása eltér a HBV-tôl, mivel nem rendelkezvén reverztranszkriptáz-aktivitással, nem épül be a májsejtgenomba, azonban több olyan fehérjét tartalmaz, amelyek a krónikus gyulladás mellett elősegítik a májsejt mutációját, a HCC kialakulását.

A hepatitis C-vírus az immunrendszer befolyásolása révén csökkenti a szervezet tumorsejt-eliminációs képességét, ami szintén hozzájárul a HCC kialakulásához és annak progressziójához.

\section{A HCC kockázati tényezői}

A májrák kialakulására az egyik legfóbb kockázati tényezô maga a májcirrhosis. Etiológia szerint a vírusok (HBV, HCV), toxinok (alkohol, aflatoxin), metabolikus betegségek (diabetes, nem alkoholos steatohepatitis, hereditaer haemochromatosis) és immunmediált betegségek (PBC), valamint az autoimmun hepatitis a HCC fó rizikófaktorai [6]. Magyar szerzők már ötven évvel ezelőtt közöltek adatokat a májcirrhosis és a májrák kapcsolatáról [7].

\section{A HCV-fertőzésben előforduló HCC epidemiológiája}

Már a HCV felfedezése előtt felfigyeltek az akkor még non-A-non-B-nek (NANB) nevezett hepatitis és a májrák közötti kapcsolatra. A későbbi epidemiológiai jellegü tanulmányok ezt megerösítették $[8,9,10]$.

Nyugat-Európában és Észak-Amerikában a $\mathrm{HCV}$ a leggyakoribb rizikófaktor, amit jól mutat, hogy epidemiológiai tanulmányok szerint a HCC-s betegek 50\%ának a szérumában anti-HCV-antitestek mutathatók ki. Japánban ez az arány eléri a 70\%-ot [1].

A májrák gyakoribb a $\mathrm{HCV}$-infekció talaján kialakult cirrhosisban, mint az egyéb eredetû cirrhosisokban.

\section{A perzisztáló $\mathrm{HCV}$-infekció szerepe a HCC kialakulásában}

A tartós HCV-infekció több úton járul hozzá a HCC kialakulásához. Az egyik a krónikus gyulladás és a következményesen kialakult májcirrhosis, ami önmagában hajlamosít májrák kialakulására. A másik lényeges me- chanizmus a vírus direkt mutagenitása, aminek egyre több bizonyítéka van. A HCV-fertőzött egyének 80\%-a nem képes a vírust spontán eliminálni, a betegség progrediál a krónikus gyulladás és májcirrhosis felé. A hatékony immunválasz hiánya felelős a tartós vírusinfekcióért, ami a HCC legnagyobb kockázata [2].

\section{A karcinogenezist segítő tényezők}

Bár a HCV-infekcióban előforduló HCC keletkezésének pontos mechanizmusa nem ismert, számos tényező lehetséges szerepére már fény derült. Ezeket foglaljuk össze az alábbiakban. A hepatitis C-vírus direkt és indirekt módon vesz részt a HCC patogenezisében.

\section{Citokinek}

A máj gyulladását okozó IL-6 és TNF-citokinek egyúttal a tumor keletkezését is elősegítik, mivel aktiválják az STAT-3 onkogén transzkripciós faktort. Ez a mechanizmus az obesitashoz társuló gyulladásra is érvényes [3].

Az IL-18 egy proinflammatorikus citokin, ami HCV-infekcióban túlszabályozott. Ennek a citokinnek szerepe lehet a HCV-függő HCC keletkezésében. A HCC-sejtekben expresszálódó IL-18 összefüggésben lehet a rossz prognózissal [4].

A citokinek együttmúködése által okozott gyulladás elősegíti a tumorpromóciót és a daganat progreszszióját [5].

\section{COX-2}

A proinflammatorikus citokinek, a mitogének, a tumorpromoterek és a növekedési faktorok jelenősen aktiválják a ciklooxigenáz-2 aktivitását. Újabb adatok szerint a COX-2 számos premalignus és malignus betegségben, közöttük HCC-ben is túlexpresszált, aminek szerepe lehet a hepatocarcinogenesisben. A kérdés azonban még vitatott, mert van olyan közlemény, amely szerint az enzim expressziója igen változatos, és HCC-ben kisebb, mint egyéb májbetegségekben. Negatív összefüggést találtak a tumorsejtek COX-2-aktivitása és a tumorsejtek differenciáltsági foka között [6].

\section{Apoptózis}

Krónikus HCV-infekcióban fokozott a hepatocytaapoptózis, aminek fontos szerepe van a vírus eliminációjában. Az apoptózis egy fontos élettani folyamat, amely elősegíti a szövetek homeosztázisát azáltal, hogy eliminálja a felesleges vagy rosszul funkcionáló sejteket. Krónikus HCV-infekcióban a csökkent keringő és a hepaticus Fas-expresszió nemcsak a nagyobb fokú májfibrosissal, hanem a fokozott HCC incidenciával mutat összefüggést. Az apoptotikus folyamat zavarai hozzájárulnak a tumorképződéshez [7]. 


\section{Regeneráció}

A vírus által okozott májsejtkárosodásra a máj kompenzatorikus proliferációval, regenerációval válaszol. A fokozott májregeneráció fokozza a tumor képződésének lehetőségét. Számos növekedési faktor és citokin, közöttük a hepatocytanövekedési faktor, az epidermalis growth faktor, a TGF-alfa, az IL-6, TNF-alfa, az inzulin, az IGF-1 és a noradrenalin, mind fontos szerepet játszanak ebben a folyamatban [8].

A fibroblastnövekedési faktor receptor-2 izoform b (FGFR2-IIIb) molekulának fontos szerepe van a máj homeosztázisában, a máj regenerációjában. A HCCsejtekben az FGFR2-IIIb csökkent expressziója a tumorsejtek agresszívebb növekedésével mutatott összefüggést [9].

A májsejtpusztulás és a májsejt-proliferáció közötti egyensúly szabályozásának zavara elősegíti a hepatocarcinogenesist. Az antiapoptotikus NF- $\kappa \mathrm{B}$ útvonal túlzott aktivációja apoptózissal szembeni rezisztenciát eredményezhet. A máj gyulladása a különböző citokinek - mint a TNF-alfa, kemokinek, interleukinek és vírusproteinek - összehangolt hatása révén aktiválja az NF- $\kappa \mathrm{B}-\mathrm{t}$, ami nagy valószínúséggel elősegíti a praecancerosus hepatocyták túlélését [20]. Az inzulin-IGF-1 jelátvitel fokozza az NF- $\kappa \mathrm{B}$-hatást.

\section{Megváltozott jelátviteli események}

Számos kutató kimutatta májrákban a fó jelátviteli mechanizmusok megváltozott aktivációját. Májrákok nagy részében a Fas-útvonal molekuláinak egy vagy több eltérése figyelhető meg, amelyek gátolják a Fas által mediált apoptózist. A Fas és a FasL expressziójának státusa elörejelezheti mind a $\mathrm{HCV}$, mind a $\mathrm{HBV}$ által indukált HCC visszatérését [2].

Az IGF jelátviteli rendszer szabályozásának megváltozása is gyakori HCC-ben. Az IGF-1 a tumorsejtek hatékony növekedési faktora. Az IGF-1 túlzott expreszsziója serkenti a tumornövekedést. Az IGF-2-expresszió gyakran indukált állapotba kerül HCC-ben, és a szérumIGF-2-szint a májon kívüli áttétek jelenlétével mutat összefüggést [22].

\section{Oxidatív stressz}

Hepatitis C-fertőzésben a szabad gyökök, a ROS/RNS szintje fokozott, és ugyanakkor az antioxidánsok szintje csökkent. Az oxidatív stressznek fontos szerepe van a hepatitisvírusok által indukált gyulladásban és a HCC keletkezésében.

Elbúzódó endoplazmás reticulum (ER) -stressz. Az oxidatív stressz elhúzódó endoplazmás reticulum (ER) -stresszt és a kóros fehérjék felhalmozódását okozza. A HCV az oxidatív stressz révén megváltoztatja az endoplazmás reticulumban a $\mathrm{Ca} 2+$-homeosztázist.
A HCV-fehérjék által indukál ER- és oxidatív stressz a HCV-transzformációhoz is hozzájárulnak [23].

Mitokondriális müködési zavar. HCV-infekcióban a mitokondriumok múködésének zavara az oxidatív stressz legfőbb forrása.

Tumorral összefüggó jelátvitel módosulása. Az oxidatív stressz a MAPK intracelluláris jelátviteli rendszer aktiválása révén, a sejtszaporodás szabályozásának megváltoztatása útján elősegíti a malignus átalakulást.

Fibrosis, kontrollálatlan proliferáció. A vírus szaporodása által indukált oxidatív stressz is hozzájárul a fokozott csillagsejt-aktivációhoz, és ezúton a fibrogenezishez és a fokozott májsejt-proliferációhoz [24].

\section{Angiogenezis}

A HCV által okozott májrák keletkezésében és növekedésében is fontos szerepe van az angiogenezisnek. A VEGF és annak receptora HCC-ben túlszabályozott mind a tumorban, mind a szérumban. A legújabb tumorellenes gyógyszernek, a multitirozináz-gátló sorafinebnek az egyik támadáspontja itt van.

\section{A genetikai eltérések halmozódása}

A májsejtek mutációja, a genetikai hibák többlépcsős halmozódása szükséges a májrák kialakulásához [25]. HCV-infekcióban számos ilyen eltérést írtak le.

A P53 tumorszuppresszor gén inaktiválása. A HCVcore proteinje képes a P53 inaktivációjára. A HCV által indukált P53-mutációk gyakoriak. A HCC-s betegek szérumában P53-antitesteket mutattak ki. Mindezek együttesen a májrák kialakulásához és progressziójához vezethetnek.

A HCV-1b core gén szerepe. Eddig nyolc jellemző mutációt mutattak ki a HCV-core-1b génben, amelyek a HCC előfordulásával összefüggenek [26].

Bcl-2 család. Hepatocellularis carcinomában számos genetikai eltérést megfigyeltek, amelyek a $\mathrm{Bcl}-2$ család pro- és antiapoptotikus tagjainak egyensúlyzavarához vezetnek.

\section{Az epigenetikus sejtmechanizmusok kóros változása}

DNS-metiláció. A DNS-metiláció megváltoztatja, gátolja a tumorszuppresszor géneket. Kóros metiláció a praecancerosus nodulusokban, mint a dysplasiás göbökben és az adenomákban is megfigyelhető, ami arra utal, hogy az epigenetikus eltérések hepatocarcinogenesis korai eseményei. Felvetették azt is, hogy HCVinfekcióban az epigenetikus eltérések az oxidatív stressz következményei lennének [27, 28].

Febérjeglikolizáció hiánya. Lehetséges, hogy a membránproteinek glikolizációja zavarának is szerepe van a tumorképződésben [29]. 


\section{Vasfelhalmozódás}

A máj vastartalmának növekedése független kockázati tényező HCC-re. Tankönyvi adat, hogy haemochromatosisban a májrák kockázata kétszázszor nagyobb. HCV-fertőzésben gyakori a fokozott vastárolás.

\section{Inzulinrezisztencia és zsírmáj szerepe}

Bizonyított, hogy diabetes mellitusban a HCC kockázata nagyobb, ami a cukorbetegség fennállásának időtartamával és a kezelésre alkalmazott gyógyszerekkel összefüggést mutat [30]. Az inzulinrezisztenciát csökkentő gyógyszerek alkalmazása esetén kisebb a májrák kockázata. Kiderült, hogy az inzulinrezisztencia cukorbetegség nélkül, önmagában is fokozza a májrák kockázatát [31]. Krónikus C-hepatitisben az inzulinrezisztencia és a 2-es típusú diabetes mellitus gyakoribb, mint az egészségesekben és hepatitis B-vírus-fertőzöttekben. A HCV különböző mechanizmusok révén okoz inzulinrezisztenciát a májbetegség súlyossági fokától függetlenül. Az inzulinrezisztencia egyik fontos tényezője a hepatocarcinogenesisnek [32]. A HCV által indukált gyulladás, az inzulinrezisztencia és a zsírmáj kölcsönösen hatnak egymásra és ezúton is fokozzák a májrák kialakulásának kockázatát. A HCV indukálja a gyulladást elősegítő TNF-alfa és az IL-6 termelődését, amelyek proonkogén hatásúak és inzulinrezisztenciát okoznak. A mechanizmusban a nukleáris PPAR-gammareceptornak is szerepe van.

A HCV-fertőzés és a zsírmáj kapcsolatát főleg a 3-as genotípus esetén figyelték meg, de a más genotípusú infekcióban is előfordul. A zsírmáj fokozza az inzulinrezisztenciát. A transzgén egerekben tett megfigyeléseket a humán adatok is megerősítik $[33,34]$. Az inzulinrezisztencia szerepét mutatja, hogy rádiófrekvenciás tumorablatiót követően a HCC-recidíva gyakoribb volt azokban a betegekben, akikben a magasabb HOMA(homeostatic model assessment of insulin resistance) érték inzulinrezisztenciát bizonyított [3].

\section{Direkt genotoxikus mechanizmusok}

A hepatitis C-vírusnak több olyan proteinje is van, amely direkt onkogén hatással rendelkezik. Részben ezeknek tulajdonítják, hogy a HCC olyan HCV-fertözöttekben is kialakul, akiknek nincs cirrhosisuk. A corefehérjék mellett a burokglikoproteinek és a nem strukturális gének onkogén szerepét is kimutatták.

\section{$H C V$-cove fehérjék}

Összefüggést találtak a HCV-core fehérje génmutációi és a HCC között. Az eddig azonosított 24 mutáció közül 8 (A028C, G209A, C219U/A, U264C, A271C/U, C378U/A, G435A/C és G481A) esetében szignifikán- san nagyobb a HCC kockázata. Az U303C/A-mutáció viszont csökkent kockázattal társult [26].

A HCV-core gén mutációit különbözőnek találták azokban a betegekben, akikben HCC alakult ki, mint azokban, akikben nem lehetett májrákot kimutatni. A HCV-core gén több pontján találtak különbséget a nem cirrhoticus májban és a cirrhosis talaján kialakult HCC-ben [35].

Indirekt bizonyítéknak tartható, hogy a HCV-core protein fokozza a humán hepatomasejtek proliferációját a TGF-alfa, NF- $\kappa B$ és MARK/ERK útvonal aktiválása révén [36].

A HCV-core protein önmagában és más fehérjékkel együtt is fokozza az androgén receptor által közvetített jelátvitelt, aminek szerepe lehet a karcinogenezisben. A HCV-core fehérje aktiválja az STAT3-at, ami erôsíti az androgénreceptor-jelátvitelt, ami fokozza az egyik célmolekula, a vascularis endothelialis növekedési faktor (VEGF) képződését, aminek pedig fontos szerepe van a tumornövekedést elősegítő angiogenezisben [37].

A core-protein indirekt utakon is hozzájárulhat a karcinogenezishez. Többek között az inzulin-jelátvitel gátlásán, az inzulinreceptor-szubsztrát (IRS) protein degradációján keresztül [38], a szabad gyökök generálása, az oxidatív stressz által fokozott inzulinrezisztencia révén, a TNF-alfa mediálta apoptózis gátlása útján, az infekció elleni védekezés gyengítésével, a mitokondriumok külső membránjában a $\mathrm{Ca} 2+$-felvétel fokozása, a membránpermeabilitás növelésével külön-külön és együttesen elősegíti a karcinogenezishez szükséges mikrokörnyezet kialakulását.

\section{Envelope glikoproteinek}

A hepatitis C-vírus-burok (envelope) glikoproteinje endoplazmatikus stresszt és olyan fehérjeválaszt indukál, ami befolyásolja a vírusreplikációt, a COX-2-aktivitást, a vírus és a gazdasejtek közötti kölcsönhatást [39]. További vizsgálatok szükségesek annak megállapításához, hogy a tumorképződésben lehet-e szerepe.

\section{Nem strukturális gének}

Újabb adatok szerint a hepatitis C-vírus NS5A fehérje kölcsönhatásba lép a béta-kateninnel és stimulálja annak transzkripciós aktivitását, aminek szerepe lehet a HCVinfekció krónikussá válásában és a HCC kialakulásában [40].

\section{A hepatocarcinogenesis tisztázásra váró kérdései}

A fentebb felsorolt számos jól ismert tényező ellenére sem ismert a májrák keletkezésének pontos mechanizmusa. Tisztázásra vár, hogy miért nem alakul ki minden 
hepatitis C-infekcióban szenvedő betegben májrák. Mai ismereteink szerint a daganat egy sejt mutációjából indul el és szaporodik kontroll nélkül. Nem tisztázott, hogy azok az okok, ami miatt az immunrendszer nem képes eliminálni a vírust, vajon milyen szerepet játszanak abban, hogy a tumorsejtek eliminációjára sem kerül sor, és hogy azok kontroll nélkül képesek proliferálni. Újabb adatok szerint nem csak a vírus, hanem a gazdaszervezet genetikai adottságai is jelentősen befolyásolják az infekció lefolyását, az antivirális kezelésre adott válaszát. További vizsgálatok szükségesek annak feltárására, hogy a májrák keletkezését mennyire befolyásolják a szervezet genetikai adottságai, a HCV és a környezeti tényezők együttesen.

A HCV-fertőzött betegekben kialakult májrák szövettani képe, klinikai diagnosztikája és kezelési lehetőségei nem térnek el az egyéb kiváltó okok által indukált hepatocellularis carcinomáétól. A jövő kutatási eredményei adhatják meg a választ a ma még számos nyitott kérdésre.

\section{Irodalom}

[1] Kiss A., Lotz G., Kaposi Novák P. és mtsa: Hepatitis vírusok és hepatocarcinogenezis. Orv. Hetil., 2002, 143, 83-86.

[2] Montalto, G., Carvello, M., Giannitrapani, L. és mtsai: Epidemiology, risk factors, and natural history of hepatocellular carcinoma. Ann N Y Acad. Sci., 2002, 963, 13-20.

[3] El-Serag, H. B.: Epidemiology of hepatocellular carcinoma in USA. Hepatol. Res., 2007, 37, 888-894.

[4] El-Refaie, A., Savage, K., Bhattacharya, S. és mtsai: HCV-associated hepatocellular carcinoma without cirrhosis. J. Hepatol., 1996, 24, 277-285.

[5] Madhoun, M. F., Fazili, J., Bright, B. C. és mtsai: Hepatitis C prevalence in patients with hepatocellular carcinoma without cirrhosis. Am. J. Med. Sci., 2010, 339, 169-173.

[6] Parikh, S., Hyman, D.: Hepatocellular cancer: a guide for the internist. Am. J. Med., 2007, 120, 194-202.

[7] Korpássy B., Sólyom A.: Majcirrhosis és májrák. Orv. Hetil., 1961, 102, 2353-2358.

[8] Purcell, R. H.: Does, non-A, non-B hepatitis cause hepatocellular carcinoma? Cancer Detect. Prev., 1989, 14, 203-207.

[9] Watanabe, ., Harada, S., Saito, I. és mtsai: Prevalence of antibody against the core protein of hepatitis $\mathrm{C}$ virus in patients with hepatocellular carcinoma. Int. J. Cancer, 1991, 30, 340-343.

[10] Tanaka, K., Hirobata, T., Koga, S. és mtsai: Hepatitis C and hepatitis $B$ in the etiology of hepatocellular carcinoma in the Japanese population. Cancer Res., 1991, 51, 2842-2847.

[11] Nishioka, K., Watanabe, J., Furuta, S. és mtsai: A high prevalence of antibody to the hepatitis $\mathrm{C}$ virus in patients with hepatocellular carcinoma in Japan. Cancer., 1991, 67, 429-433.

[12] Castello, G., Scala, S., Palmieri, G. és mtsai: HCV-related hepatocellular carcinoma: From chronic inflammation to cancer. Clin. Immunol., 2010, 134, 237-250.

[13] Park, E. J., Lee, J. H., Yu, G. Y. és mtsai: Dietary and genetic obesity promote liver inflammation and tumorigenesis by enhancing IL-6 and TNF expression. Cell, 2010, 140, 197-208.

[14] Perrella, O., Cuomo, O., Sbreglia, C. és mtsai: IL-18 and interferon-gamma in HCV-related hepatocellular carcinoma: a model of interplay between immune status and cancer. J. Biol. Regul. Homeost. Agents, 2009, 23, 251-258.

[15] Lin, W. W., Karin, M.: A cytokine-mediated link between innate immunity, inflammation, and cancer. J. Clin. Invest., 2007, 117, $1175-1183$
[16] Giannitrapani, L., Ingrao, S., Soresi, M. és mtsai: Cyclooxygenase-2 expression in chronic liver diseases and hepatocellular carcinoma: an immunohistochemical study. Ann. N Y Acad. Sci., 2009, 1155, 293-299.

[17] El Bassiouny, A. E., El-Bassiouni, N. E., Nosseir, M. M. és mtsai: Circulating and hepatic Fas expression in HCV-induced chronic liver disease and hepatocellular carcinoma. Medscape J. Med., $2008,10,130$.

[18] Michalopoulos, G. K., DeFrances, M. C.: Liver regeneration. Science, 1997, 276, 60-66.

[19] Amann, T., Bataille, F., Spruss, T. és mtsai: Reduced expression of fibroblast growth factor receptor $2 \mathrm{IIIb}$ in hepatocellular carcinoma induces a more aggressive growth. Am. J. Pathol., 2010, $176,1433-1442$.

[20] Fabregat, I.: Dysregulation of apoptosis in hepatocellular carcinoma cells. World J. Gastroenterol., 2009, 15, 513-520.

[21] Bortolami, M., Kotsafti, A., Cardin, R. és mtsai: Fas/FasL system, IL-lbeta expression and apoptosis in chronic HBV and HCV liver disease. J. Viral Hepat., 2008, 15, 515-522.

[22] Chen, Y. W., Boyartchuk, V., Lewis, B. C.: Differential roles of insulin-like growth factor receptor- and insulin receptor-mediated signaling in the phenotypes of hepatocellular carcinoma cells. Neoplasia, 2009, 11, 835-845.

[23] Levrero, M.: Viral hepatitis and liver cancer: the case of hepatitis C. Oncogene., 2006, 25, 3834-3847.

[24] Clément, S., Pascarella, S., Conzelmann, S. és mtsai: The hepatitis $\mathrm{C}$ virus core protein indirectly induces alpha-smooth muscle actin expression in hepatic stellate cells via interleukin-8. J. Hepatol., 2010, 52, 635-643.

[25] Koike, K.: Pathogenesis of HCV-associated HCC: Dual-pass carcinogenesis through activation of oxidative stress and intracellular signaling. Hepatol. Res., 2007, 37, S115-S120.

[26] Hu, Z., Muroyama, R., Kowatari, N. és mtsai: Characteristic mutations in hepatitis $\mathrm{C}$ virus core gene related to the occurrence of hepatocellular carcinoma. Cancer Sci., 2009, 100, 2465-2468.

[27] Nishida, N.: Impact of hepatitis virus and aging on DNA methylation in human hepatocarcinogenesis. Histol. Histopathol., 2010, 25, 647-654.

[28] Hagymási, K., Tulassay, Z.: Az elsődleges májrák epidemiológiája, kóroka és kialakulásának molekuláris háttere. Orv. Hetil., 2008, 149, 541-548.

[29] Lee, A., Chick, J. M., Kolarich, D. és mtsai: Liver membrane proteome glycosylation changes in mice bearing an extra-hepatic tumour. Mol. Cell. Proteomics, 2010, Feb 18. [Epub ahead of print]

[30] Hassan, M. M., Curley, S. A., Li, D. és mtsai: Association of diabetes duration and diabetes treatment with the risk of hepatocellular carcinoma. Cancer, 2010, 116, 1938-1946.

[31] Imai, K., Takai, K., Nishigaki, Y. és mtsai: Insulin resistance raises the risk for recurrence of stage I hepatocellular carcinoma after curative radiofrequency ablation in hepatitis $\mathrm{C}$ virus-positive patients: A prospective, case series study. Hepatol. Res., 2010, 40, 376-382.

[32] Kawaguchi, T., Sata, M.: Importance of hepatitis C virus-associated insulin resistance: Therapeutic strategies for insulin sensitization. World J. Gastroenterol., 2010, 16, 1943-1952.

[33] Schaff, Zs., Lotz, G., Eder, G. és mtsa: Pathomorphology and apoptosis in viral hepatitis. In: Therapies for viral hepatitis. Eds: Schinazi, R. F., Sommadossi, J. P., Thomas, H. Int. Med. Press Ltd. London, 1998, 77-86.

[34] Koike, K.: Steatosis, liver injury, and hepatocarcinogenesis in hepatitis C viral infection. J. Gastroenterol., 2009, 44, 82-88.

[35] Fishman, S. L., Factor, S. H., Balestrieri, C. és mtsai: Mutations in the hepatitis $\mathrm{C}$ virus core gene are associated with advanced liver disease and hepatocellular carcinoma. Clin. Cancer Res., $2009,15,3205-3213$

[36] Sato, Y., Kato, J., Takimoto, R. és mtsai: Hepatitis C virus core protein promotes proliferation of human hepatoma cells through 
enhancement of transforming growth factor alpha expression via activation of nuclear factor-kappaB. Gut, 2006, 55, 18011808.

[37] Kanda, T., Steele, R., Ray, R. és mtsa: Hepatitis C virus core protein augments androgen receptor-mediated signaling. J. Virol., 2008, 82, 11066-11072.

[38] Serfaty, L., Capeau, J.: Hepatitis C, insulin resistance and diabetes: clinical and pathogenic data. Liver Int., 2009, 29, 13-25.

[39] Chan, S. W., Egan, P. A.: Effects of hepatitis C virus envelope glycoprotein unfolded protein response activation on translation and transcription. Arch. Virol., 2009, 154, 1631-1640.
[40] Milward, A., Mankouri, J., Harris, M.: Hepatitis C virus NS5A protein interacts with beta-catenin and stimulates its transcriptional activity in a phosphoinositide-3 kinase-dependent fashion. J. Gen. Virol., 2010, 91, 373-381.

(Szalay Ferenc dr., Budapest, Korányi S. u. 2/A, 1083 e-mail: szalay@bell.sote.hu)

\section{A Kiskunfélegyházi Városi Kórház-Rendelöintézet Gyógyfürdő és Rehabilitációs Központ (6100 Kiskunfélegyháza, Fadrusz J. u. 4.) pályázatot hirdet \\ Sebészeti szakrendelésén 1 fö részére, szakorvosi munkakör betöltésére.}

Feladat: a munkaköri leírásban foglaltak alapján a szakirányú képesítésnek megfelelő szakorvosi tevékenység végzése.

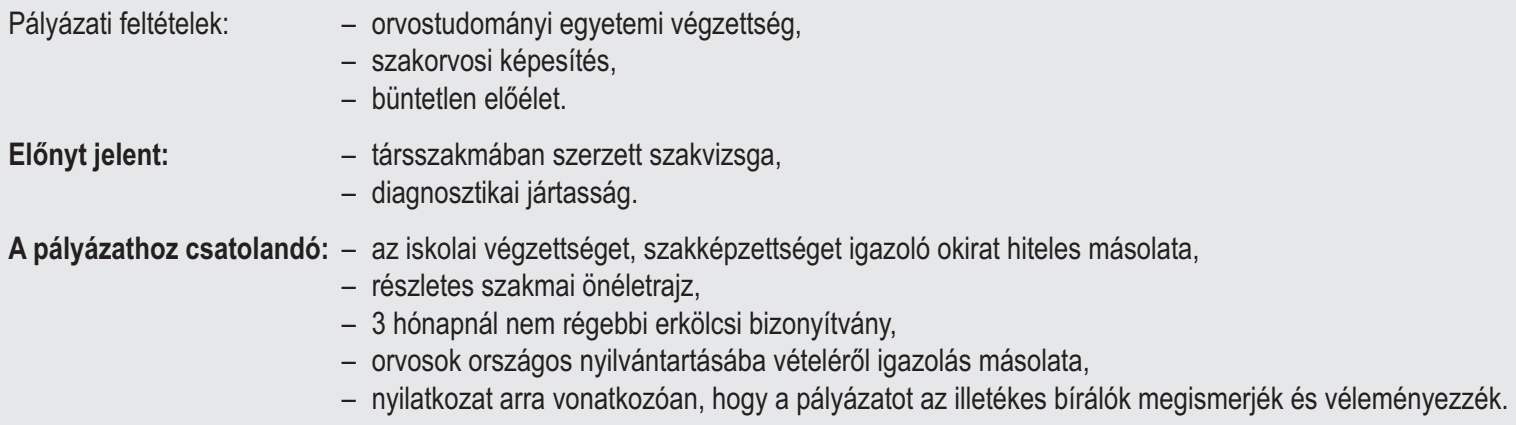

Bérezés: a Kjt. rendelkezései szerint.

A pályázat benyújtásának határideje: $\quad$ 2010. szeptember 30 .

A pályázat elbírálásának határideje: $\quad$ 2010. október 10.

Az állás a pályázati elbírálást követően, 2010. október 15-étől tölthető be.

A pályázatokat a fenti címre,

Dr. Kovács József főigazgató főorvosnak címezve kell benyújtani, személyesen vagy postai úton.

Postai benyújtás esetén a boritékon kérjük feltüntetni:

"Sebész szakorvosi pályázat" 